\title{
Fedele Fischetti and the Gallery of the Royal Casino of Carditello in Caserta (Italy)
}

\author{
Antonella Diana \\ The Royal Palace of Caserta, Caserta, Italy \\ Email address: \\ antonella.diana $@$ beniculturali.it

\section{To cite this article:} \\ Antonella Diana. Fedele Fischetti and the Gallery of the Royal Casino of Carditello in Caserta (Italy). International Journal of Literature and \\ Arts. Vol. 7, No. 2, 2019, pp. 54-60. doi: 10.11648/j.ijla.20190702.14
}

Received: October 14, 2018; Accepted: May 21, 2019; Published: June 26, 2019

\begin{abstract}
The Royal residence of Carditello, known as "Royal Casino", is considered one of the most beautiful and architecturally refined Reali Delizie "ville de delizie" made by King Ferdinand of the house of Bourbon. Commissioned in the spring of 1784 for the purpose of providing necessary rural housing for the King's animals, processing related products, and providing housing for staff, Carditello was much loved by the King. In 1787, work began on building up the small "Casino" (or "country house") designed by Francesco Collecini. Fully furnished, the royal residence made a display of beautiful curtains, a rich art gallery and a multitude of books, as documented by the first inventory of the site, prepared immediately after its completion in 1792. In the official documents called Amministrazione di Carditello e Calvi - Conti e Cautele preserved in the Historical Archives of the Royal Palace of Caserta, there are various records that attest to the payments for work done at the apartment of the king in "Cardito" by Fedele Fischetti, and thanks to them we have been able to reconstruct the existence of works by the Neapolitan Fischetti in the Gallery of Carditello. The Gallery of Carditello, which was the main hall of the building, was commissioned and intended to be the more opulent and richer space in the apartment where Fedele Fischetti painted the frescos on the vault, drew the preparatory models of tapestries and perhaps prepared the designs for the magnificent and expensive furniture of French production.
\end{abstract}

Keywords: Royal Casino of Carditello, Bourbon Dynasty, Fedele Fischetti, Neapolitan Painter, Archival Documents

\section{Introduction}

Having ascended to the throne of Naples on 1734, Charles of Bourbon (Madrid 1716-1788), when the incredible discoveries and archaeological excavation campaigns of the Vesuvian sites were carried out with keen interest, started the establishment of the "Reali Delizie" involving radical changes in the Kingdom. The Royal Sites were a source of pride and dynastic power, driven by political, economic and military needs: purchases, exchanges and confiscation of feuds of the Austrian nobles led to the relaunching of the territories through the use of agricultural and manufacturing productive structures by introducing modern techniques. The Bourbon model forged by the Enlightenment ideasto which it was referred, was "noble company" model, a dynamic structure based on modern agronomic criteria, with manor house, vineyard, rooms for the processing and the preservation of agricultural products, service frameworks, in short, everything that was necessary for the best use of the territory.

\section{The Real Site of Carditello and Its Decorative Program}

\subsection{The Real Site of Carditello: Historical Elements}

The Carditello and its small palace are closely linked to the strategic importance of hunting, for the marshes in the area that constituted the natural habitat of pheasants and woodcocks, and of horse breeding. The Royal Casino is located in a vast flat territory [then] belonging to the family of the Earl of Acerra, Ferdinand III de Cardenas [1], who owned the property since 1628 . The Site in Terra di Lavoro, not far from the town of San Tammaro (CE), was considered by Charles of Bourbon especially suitable to perfecting the breeding of horses [2], so he buys it in 1744 « for 2800 ducati» [3]. Ferdinand IV continued the project of extending the estate with various territories, including by purchasing them or legal rights granted him. "Ferdinand [IV] loved 
Carditello and would commission - since the spring of 1784 [4] - the creation of comfortable rural estate necessary for housing animals, processing of products and the homes of staff' [5]. In 1787, work began on building up of the small Royal Casino, designed by Francesco Collecini (Rome 1723 - Caserta 1804) [6]. The royal apartment, centrally located, is flanked by buildings devoted to agriculture and farms, all peculiarly Bourbon. Also this royal residence - as is also the case in San Leucio, but with respect to a completely different industry - sees the coexistence of farmers and dairymen in the same space in which the apartments of the sovereigns were located. The work on the Royal Casino of Carditello was completed in five years, from 1787 to 1792. The classically decorated facades gave the Royal Casino, then as now, a harmonic vision.

Fully furnished, the royal apartments had precious draperies, an extensive art gallery and a multitude of books, as documented by the first inventory of the site drafted taken immediately after its completion: the "General Inventory Of the Royal Residence of Carditello made on May 25, 1792 Royal Casino of Carditello "[7]. To German painter Jacob Philipp Hackert was entrusted the art direction of the decoration and furnishings of the Casino of Carditello. Hackert influenced the last two decades of the Neapolitan culture in the eighteenth century with a clear change of the artistic flavor. The leitmotiv of the entire project decorative of the Royal Casino of Carditello was rural world and hunting, taking into account the primitive idea of creating at Carditello a "possible dream": a proper model farm for agricultural cultivation and breeding of fine breeds of horses and cattle. Hackert also influenced many painters of rococo style, some of whom were his excellent collaborators in the decoration of Carditello including painter Fedele Fischetti. Valuable information on the progress of work at Carditello is provided by Johann Wolfgang von Goethe who published, on 1811, the biography of Jackob Philipp Hackert [8]. On 22 January 1799 the Neapolitan Republic was proclaimed and during the six republican months, the palace of Carditello was assaulted and occupied, suffering severe damages. On 1830, under Ferdinand II, the management of the Real Estate changed. Different times, different sovereigns, different economic and social perspectives. With the birth of the Kingdom of Italy (1861) the estate of Carditello passed to the Savoys and Victor Emmanuel III, on 1919, donated it to the National Combatant Workers (ONC) and its 2, 070 hectares were splitted and sold. On 1924 Carditello became a clashes place and the royal family moved paintings, furnishings and everything was left - in the rooms of the Royal Palace of Caserta and in the Capodimonte museum. On 1952 the real Delizia passed to the ownership of the General Consortium for the Reclamation of the Lower Basin of the Lower Volturno. The woods were cut, all that had been the greatness of the place remained a memory and the palace continued its inexorable decline as well. On 1978 the Museum of southern agriculture was established but then also the multiple objects, rare, sometimes unique pieces, dating back even to the classical age, suffered a loss. Since 2008, at the apex of the waste emergency in the Campania region, the Real
Sito of Carditello was surrounded by two state landfills: an expression and cause of the shameful abandon to which it was now left. The Consortium in recent years had contracted several debts that it could not pay, therefore the SGA (literally Activities Management Company, mainly owned by the San Paolo banking group), asked in 2010 to put Carditello's palace on auction to recover the claimed credit. From January 9, 2014, after decades of default and abandon, the Mibac, in the person of Minister Massimo Bray, returned the Carditello Real Site to the nation and to the community, with the subsequent birth of the institutional Foundation for its reuse and enhancement. Carditello is an important example for our whole territory for which we hope for the definitive fulfillment of a broad and complex development path for the environment, agriculture and culture [9].

\subsection{Fedele Fischetti: Creator and Painter of the Vault of the Carditello Gallery}

Fedele Fischetti (Naples, 1732-1792) an important neapolitan painter, in the his works - of the youthful period, marked by a well-defined classicist address - stimulated the interest of Luigi Vanvitelli, closely linked to that type of culture that Fischetti wanted as the decorator of numerous noble palaces and churches of the city of Neaples and of the main royal residences outside the capital of the Kingdom. In these vast fresco decorations, the tendency to reconcile the characteristics of the local figurative tradition, linked to the examples of F. Solimena, P. De Matteis, G. Del Po and F. De Mura, with the new classicist and academicizing instances expressed in Naples from paintings such as A. Kauffmann, F. Fuger, G. Tischbein - he found the most brilliant results. Having grown up in Naples on examples of Francesco De Mura and Giuseppe Bonito, and possibly having completed his training in Rome - Hackert is to be "the exponent of an artistic synthesis that will comply with increasing success to international trends advocated especially by Queen Maria Carolina. His works at the palace of Caserta, in Carditello and elsewhere are the best testimony of a progressive and happy adjustment to the changes introduced in the environment not only by Mengs Caserta, but also by a number of painters associated with the artistic culture of German and international"[10]. At the Real site of San Leucio and Carditello, as well as in many Neapolitan and palaces. The same Luigi Vanvitelli judged his painting "tasteful, witty in the inventions, with the union of many qualities"[11]. He was among the few who enjoyed Neapolitan preferences by the court for his ability to combine some aspects of local tradition with instances of late Baroque classicism. He enriched his picture language with inserts taken from the examples of figurative painting of Pompeii and Herculaneum, which had recently been discovered around that time, made with a rich palette of color ranges. He is a protagonist some pictorial cycles at the Royal Palace of Caserta: in 1778-79 he painted in fresco in the vault of the audience hall of the kings the Allegory of the Summer with Ceres and Proserpina and in the king's dressing room, now also referred to as fumig, the Allegory of Winter with Borea 
kidnapping Orizia. He frescoed the bathroom for use with the Aurora in the vault and with medallions and overlaps representing Le Grazie, Diana and Atteone, the Birth of Venus and Episodes of the myth of Acteon on the walls (1781-82).

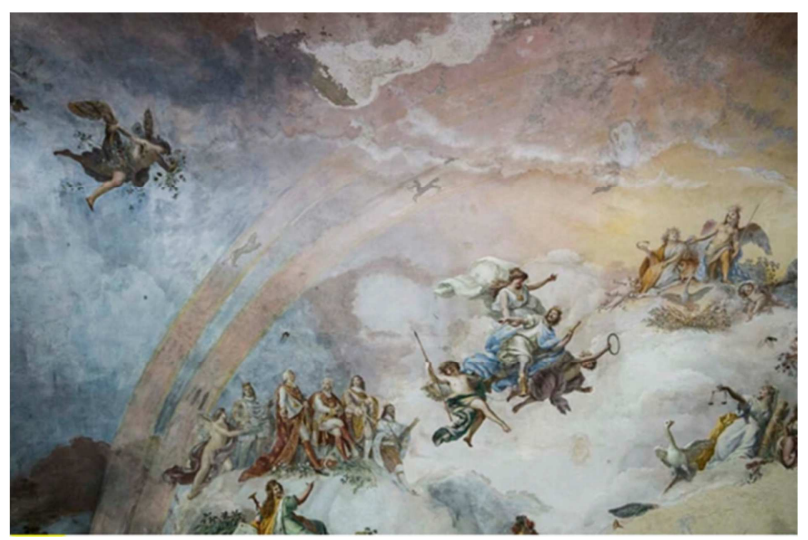

Figure 1. Fedele Fischetti, Apotheosis of Henry IV, Real Casino of Carditello, fresco in the vault of the Gallery, detail.

He painted the fresco of Venus adorned with Graces in the boudoir of the queen. Decorated the vault of the Queen's audience hall with the Allegory of the Golden Age before 1779 (of this fresco the preparatory drawing is conserved at the Cooper - Hewitt Museum in New York) and the vault of the room of the ladies with Aurora who kidnaps Mullet. In these frescos the Fischetti showed the ability to turn the stylistic preciousness of the rococo into compositions of more studied formal composure, according to the lesson of A. R. Mengs. In 1772, Fischetti created some series of refined frescoes in the Villa

Campolieto dei Casacalenda in Herculaneum, completed on drawings by Vanvitelli. In one of the rooms on the main floor it represented some scenes of court life under a fake arbor animated by putti and birds, reaching one of the happiest outcomes of rocaille painting.

\subsection{The Real Site of Carditello: The Decoration and Furnishings of the Gallery}

The study of certain historical documents found in the Historical Archive of the Royal Palace of Caserta, in particular in the file called "Amministrazione di Carditello e Calvi Conti e Cautele", one can trace the payments made for the work done at the apartment of the king at Carditello by the Neapolitan painter Fedele Fischetti. By analyzing them, we reconstructed the existence - in the Gallery of the Casino - of a real body of Fischetti's work. Constructured by Ferdinand of the house of Bourbon, the Carditello estate and its Royal Casino are considered among the most beautiful and architecturally refined of King Ferdinand's "Reali Delizie".

The Gallery of the Royal Casino of Carditello - in the central part of the apartment on the south side - is the main hall of the building. Intended to be the most opulent and rich area of the entire apartment, it was decorated with fine tapestries on the doors: the hangings of the six «mezzi portieri di amuer verde, ognuno composto da tre ferze arricchite da frangia di seta gialla torta e ritratta, $[. .$.$] mentre$ le zinefre $[. .$.$] composte da due ferze [. .$.$] sono realizzate in$ amuer molignana» (there are draperies at the windows of amuer green, each consisting of three parts decorated with yellow silk fringe, composed of two parts made amuer molignana) as is identified in the Inventory of 1792.

Ferdinand - consistent with the taste of his predecessors: his grandfather Philip V of Spain and his father Charles decided that the gallery walls had to be decorated with tapestries, and with a spirit of exaltation of the Bourbon dynasty and the virtues of his ancestors and he dedicated this cycle to the stories of Henry IV, the Bourbon king of France, founder of the dynasty (King of France and Navarre Pau, 1553- Paris, 1610). Exclusively for this hall and for the bedroom, he also chose - next to the Neapolitan furniture magnificent and expensive furniture of French production, now exhibited at the Museum of Capodimonte, Naples.

Ferdinand IV will commission in 1791 the luxurious furniture to French traders the Marchands- Merciers the rue Saint-Honoré in Paris: Dominique Daguerre and Martin-Eloy Lignereux, committed in those years in various European royal residences [12]. This furniture, now in the National Museum of Capodimonte in Naples, already assigned by Palacios in 1979, Francesco Girardi, author of the restoration carried out in 1800 after the damages suffered in the revolution of 1799 , today is attributed by the same scholar Palacios to George Jacob (1739-1814). Regardless of who the craftsman of the furniture may be, it would be interesting to clarify to who to attribute to the design of the chair at Fedele Fischetti, architect Collecini or even to the same Hackert.

For the decoration of the Gallery are commissioned to Fedele Fischetti both pictorial models (now disappeared) of the series of tapestries destined to decorate the walls, and on the vaulted ceiling fresco. Of the pictorial models we have a thorough description in the "Inventory General Del Real Site of Cardito" of 1792 and in the payment invoice, which shows the list of the paintings that was would serve as models for the tapestries, made in the 'Reale Arazzeria Napoletana' with the direction of Pietro Duranti, in 1791 (the tapestries, silk and wool, are on display - along with the furnishings mentioned - at the Museum of Capodimonte, inv. Carditello of 1911-12, nos. 8-13).

The documents set forth a description of the subjects and show us the characters depicted in scenes intended to narrate events from the life of King Henry IV of France; in particular recovering a note, of 1796 relative to the paintings of Fischetti made as models of the tapestries, it help us clear identification of both subjects and places: King Henry IV is reconciled with the minister Sully; Three Knights lost in the Woods, [which van finding the King]; King Henry IV encounters a lost gamekeeper in the woods; The king in the kitchen of woodsman; The king recognized in the kitchen of woodsman; Henry IV receives the minister Sully who welcomes his return before the courtiers. Important events in the life of King Henry IV told by Voltaire in The Henriade published in 1728 [13]. Is told that he was 
confused in search of the road to take in order to restore peace in France. The King Henry IV always was supported by his trustworthy friend the Duke of Sully, who, in 1523, advised him to convert to Catholicism to become king of France and bring peace to the kingdom. The tapestries, therefore, lead us to the knowledge of the protagonist of the whole decoration of the gallery to fully understand its exaltation of celebration at the center of the fresco.

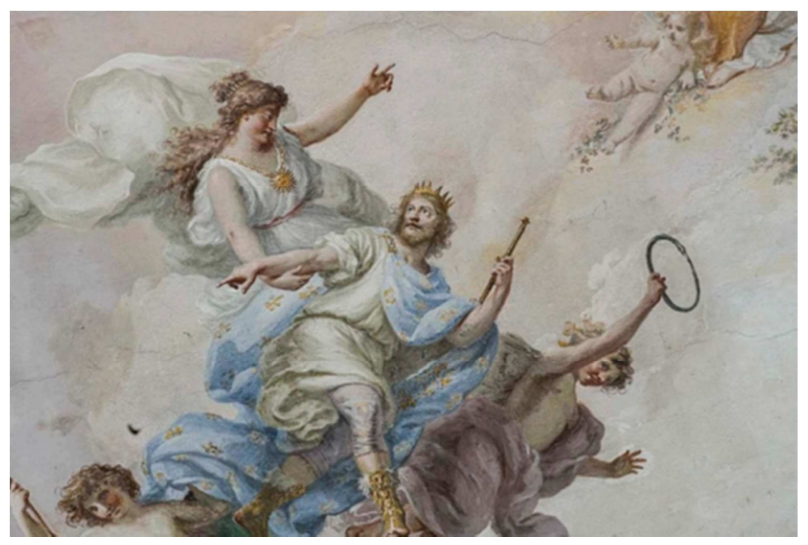

Figure 2. Fedele Fischetti, Apotheosis of Henry IV, Real Casino of Carditello, fresco in the vault of the Gallery, detail.

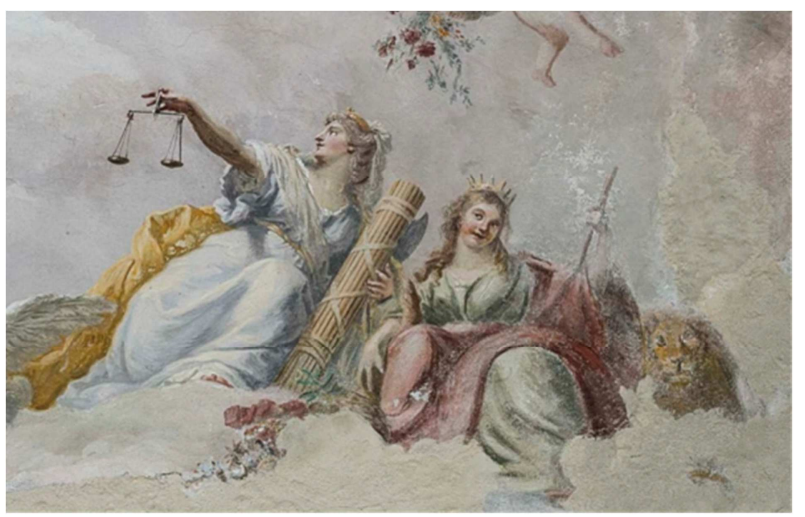

Figure 3. Fedele Fischetti, Apotheosis of Henry IV, Real Casino of Carditello, fresco in the vault of the Gallery, detail.

\subsection{The Ceiling Fresco, Last Work of Fedele Fischetti}

It was in the vault of the Gallery that Fedele Fischetti realized his last work before his death in Naples in January 25, 1792 [14], finished "just before the events of the Neapolitan Republic were to bring into that splendid fleeing international company of ambassadors, worldly, adventurers, collectors, artists, travelers and men of study he had done in the previous decade, the court of Ferdinand and Maria Carolina the most extraordinary limelight cosmopolitan end of the century, and as will be seen from an artistic standpoint, the most advanced experimental laboratory of those years»)[15].

In the fresco, the painter enhances the dynasty represented by kings Charles and Ferdinand and the birth of the Bourbon dynasty [16], "the peaceful world symbolized by the two rainbows in the fresco was represent the good government the Bourbons of Naples and of the founder of their dynasty" Henry
IV of Bourbon [17]. With the expertise of the fresco of Fischetti of May 1791, signed by Tischbein, Hackert and Collecini, it is clear the whole iconography of the work: "Apotheosis of a fourth Errigo enriched with various virtues, and Allegorical figures, together with the descendants of the Bourbons ', the latter represented by the group of bystanders where we recognize: first, Ferdinand IV of Bourbon, then reigning, Charles III of Bourbon founder of the branch of Naples and Philip V of Bourbon founder of the branch of Spain, they wear cloaks and [they] gift the scepter, but they do not have the crown. «Ferdinand is also depicted with a sword and a book, symbolizing that his government is founded on justice and wisdom; he is in the foreground because his kingdom is present, with an eye toward the virtues and glories of its founder, Henry IV, while his father Charles, and his grandfather Philip V look toward Ferdinand almost to indicate him as the designated heir». Two other characters complete the descendants of the Bourbons: the first on the far left - with youthful features - and the other, slightly detached from the group, represented in old age, both dressed in seventeenth century dress. The study of the iconography of the tapestries has identified the young person to the left as Henry III of Valois - the last member of the Valois dynasty - King of France under the name of Henry III from 1574 to 1589 (who, on August 1, 1589, was stabbed at the hands of the Catholic League) [18]. In that same year after Henry III duke of Anjou, Henry IV of Bourbon, King of Navarre, came to the throne but he was officially acclaimed in Paris - only in 1594 - as the first king of the Bourbon branch of the Capetian dynasty. So Henry III is represented in the fresco in the act of deposing the crown. the crown is offered to him by a "winged boy", that pointing with his hand the his successor in Henry IV: he was the future of France and the Bourbon dynasty. In the fresco of Gallery Henry IV is represented: in a plane slightly behind at the group of sovereigns. Fedele Fischetti built his work starting on the left with an enchanting female figure, draped in a royal robe, depicting in left hand has a sort of trumpet; behind her is placed an architectural floor plan perhaps of a ancient temple. The woman's face is turned towards the observer, while she points toward the protagonist of the Ascension bathed in light; at his feet, the painter represents the tools and symbols all the arts [19]. All of the "Liberal Arts" closely juxtaposed to a cornucopia, symbol of abundance, overflowing with buds, leaves and ripe fruits pomegranates both closed and open, pears and apples, grapes and so much a branch with ripe cherries. Fruits and plenty symbolizing the Campania Felix beloved first by Charles and then by Ferdinand: the clear will of the Bourbon kings is to present themselves as reformers, protagonists of the Age of Enlightenment in a land still ruled by rigid rules and laws of feudal legacy, where they initiate innovations that express broad cultural openness. "Many of the symbols described above reflect obvious references to Masonic culture [20]. In the XVIII century "Freemasonry" was largely rooted in the southern areas among the aristocrats and Queen Maria Carolina has showed all her support of for them: so it can be assumed that the female figure in the foreground, which appears to be wrapped a in a royal robe, is identifiable 
with the Queen herself who - through support to artists and nobles near the "Lodge of Free Masons" - would be she of the "supporters" of the new and good Bourbon government. The merits that led Henry IV to that elevation are identifiable in the at group to the right of the painting. The symbolic figures and the same tools that are depicted confirm that Henry exercised "justice" and united the people with examples of "righteousness," "temperance" and "'fairness". Next to the image of Justice is a crowned woman with a scepter in her hand, perhaps the same Queen Maria Carolina; beside her the figure of a lion, the symbol of "fortress". A large gap does not allow us to complete the reading (you can see only a winged figure holding up a trumpet) characterized by a particular color scheme where yellow, burgundy and green highlight the monumental figures, wrapped in a bright light. In the highest part [of the painting] there is a winged genius and crowned, perhaps the Victory, at his right there is a figure crowned with a laurel crown, who holds out to Henry IV a crown. He is conducted towards the Glory, because of his deeds and his policies of peace and tolerance. Its merit is that it has created a dynasty, he laid the foundations for a history of good governance and justice, he so is destined for the Apotheosis, the Gloria. At the base of the group is placed a burning bush with the Phoenix, the sacred bird, which is always reborn from its ashes: the Apotheosis is thus synonymous with Immortality, conquered by Henry IV and hoped for by all the kings of his dynasty.

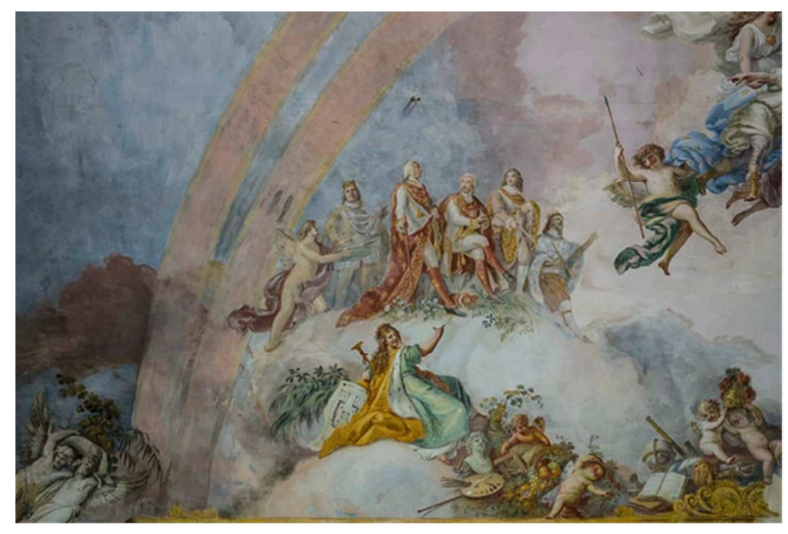

Figure 4. Fedele Fischetti, Apotheosis of Henry IV, Real Casino of Carditello, fresco in the vault of the Gallery, detail.

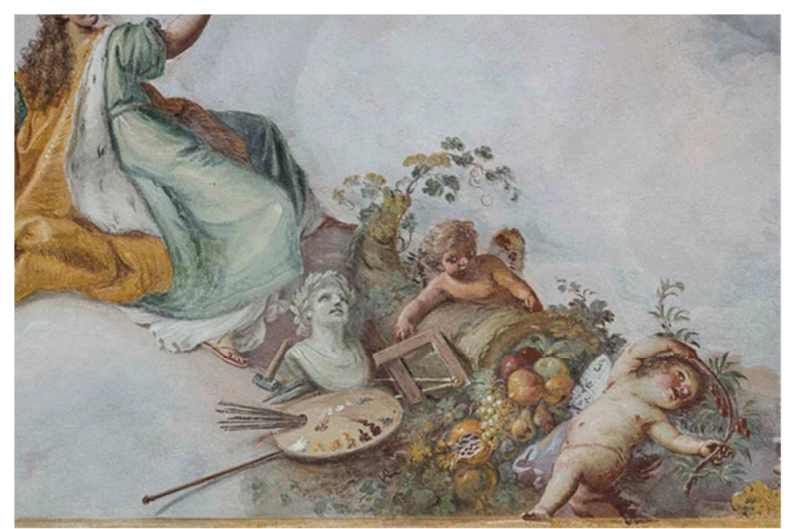

Figure 5. Fedele Fischetti, Apotheosis of Henry IV, Real Casino of Carditello, fresco in the vault of the Gallery, detail.

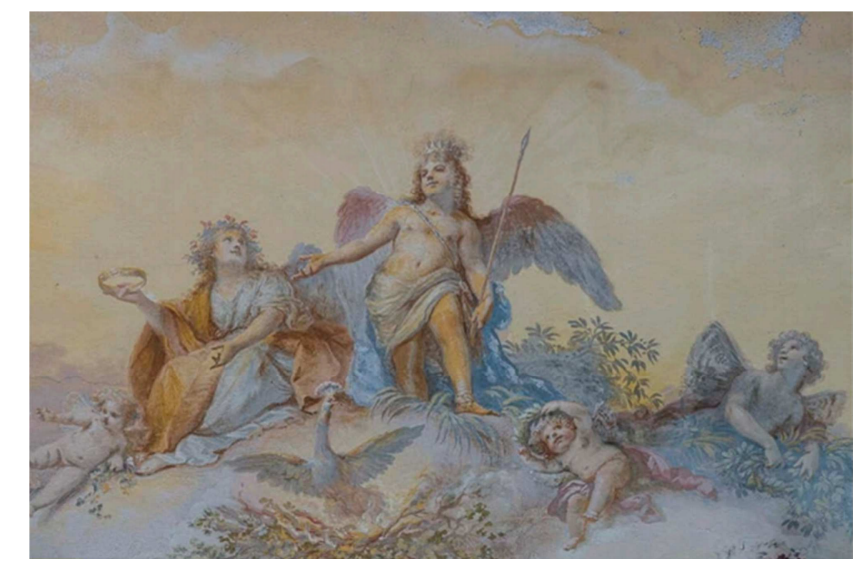

Figure 6. Fedele Fischetti, Apotheosis of Henry IV, Real Casino of Carditello, fresco in the vault of the Gallery, detail.

\section{Conclusions}

The fresco the ceiling of the gallery of Carditello is in my opinion one of the most outstanding examples of the ability shown by Fischetti to reconcile, in his old age, instances of local characters and decorative tradition, with new and recent classicist elegance derived by Batoni and Mengs. Witness of the inclination gained by the painter - in the eighties - of greater balance between the decoration and bright light of style rococo with European classicism [21]. So Fischetti, in this work, celebrates the House of Bourbon in that place, the Gallery of the Royal Casino of Carditello, which is undoubtedly the most shining symbol of an "enlightened" monarchy "of "good governance" which - through the modernization of agriculture and farms - would bring wealth and prosperity to the people.

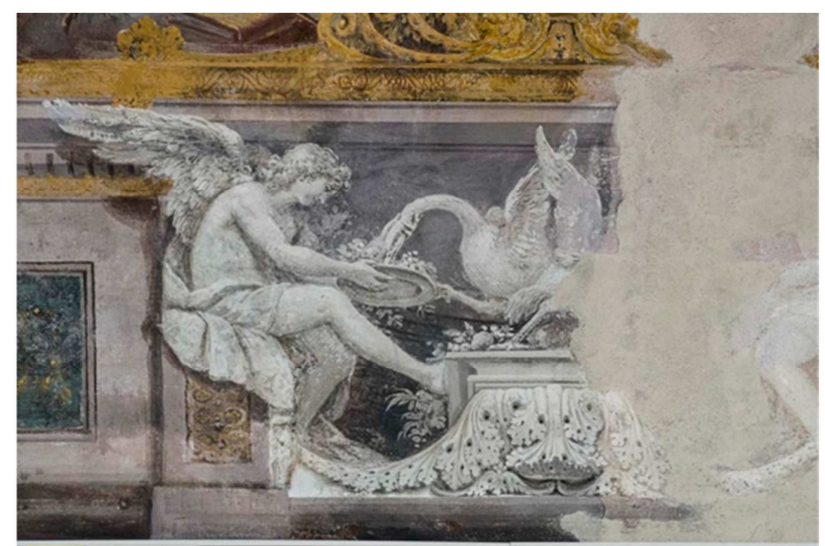

Figure 8. Fedele Fischetti, Apotheosis of Henry IV, Real Casino of Carditello, fresco in the vault of the Gallery, detail, Foto by Francesco Campanile.

\section{References}

[1] G. Caporale, Memorie storico-diplomatiche della città di Acerra e dei Conti che la tennero in feudo, Naples, 1890.

[2] G. Alisio, Siti reali dei Borboni, Aspetti dell'architettura napoletana del Settecento, Rome, 1976. 
[3] Historical archive of the palace of Caserta, Platea del Real Sito di Caserta formata per ordine di S M. Francesco I, Amministratore cavalier Sancio, vol. IV, Stato di Carditello e Calvi, v. 3571, post 1834 . The document contains the general description of the Real Site of Carditello and buildings existing in the same.

[4] In the fund called Amministrazione di Carditello e Calvi Conti e Cautele, kept at the ARC, shows expense of the workers, the technical expertise of the work done and the contracts. The numerous documents allow us to identify the different workers involved; see L. Migliaccio, Rivisitando Carditello. Nuove acquisizioni archivistiche, in "Bollettino di informazione: tutela, restauro, contributi, iniziative, mostre, manifestazioni”, n. 4, Caserta 1998.

[5] M. R. Iacono, La reale tenuta agricola di Carditello: fonti archivistiche in, Un elefante a corte: allevamenti, cacce ed esotismi alla reggia di Caserta, Naples, 1992.

[6] On the activity of Francesco Collecini, cfr. R. Serraglio, Francesco Collecini. Architettura del secondo Settecento nell'area casertana, Naples 2001 and the bibliography cited therein.

[7] ARC, General Inventory of the Royal Residence of Cardiff on the Grand Casino, the Casino of Cavallerizze, and the Tower of St. Anthony, B. 34a, f.7, year 1792, see. A. Diana, Il Real Casino di Ferdinando IV: gli arredi e gli arazzi, in rivista "Siti Reali e Territorio", special Carditello number, and L. Migliaccio, Appendice documentaria, in magazine "Siti Reali e Territorio", special Carditello number, Rome, 2014.

[8] J. W. Goethe, Biografia di J. Philippe Hackert, (reprint), Naples, 1988.

[9] cfr. AA. VV., Alle origini di Minerva Trionfante. Caserta e l'utopia di S. Leucio. La costruzione dei Siti reali Borbonici, Rome, 2012; AA. VV., Alle origini di Minerva Trionfante. L 'Unità d'Italia vista da san Leucio. I siti Reali Borbonici, Caserta e Terra di Lavoro nel processo di Unificazione nazionale, Rome, 2013; E. Ventrella - R. Ventrella, Reali Delizie. Itinerario storico artistico in Campania felix, Naples, 2013; A. Di Iorio, Carditello da feudo a Sito Reale, Verona, 2014; N. Verdile, La Reggia di Carditello, da sito reale a metafora di un'Italia in declino, Caserta, 2014.

[10] R. Lattuada, Neapolitan painting in his dealings with Luigi Vanvitelli and the court of Caserta, in The House of the King. A Century of History of the Royal Palace from 1752 to 1860 , (in cd) R. Cioffi, Milan, 2004 p. 95.

[11] N. Spinosa, Luigi Vanvitelli and painters active in Naples in the second half of the eighteenth century. Letters and unpublished documents, in Art History, 14, 1972, p. 208.

[12] A. Diana, L'arredamento del Casino Reale di Carditello, in "Siti Reali e Territori", cit. p. 32; A. González Palacios, L'arredamento del Real Casino di Carditello in "Nostalgia e invenzione, Arredi e arti decorative a Roma e Napoli nel Settecento", Milan, 2010, p. 124. The greater marchandmercier Paris, Dominique Daguerre (? - London 1796) was associated, since 1772, with the famous merchant SimonPhilippe Poirier at the store site in the rue Saint-Honoré, A la Couronne d'or, where he provided the courts and the aristocracy of half Europe. Sole proprietor of the shop in 1777, since 1787 visit London to open a shop of Sevres porcelain. In May of 1789 with a contract of association with Martin-Eloy Lignereux (1750-1809). Daguerre had sensed the climate in France after the fall of the Bastille and the relentless fall of the ancient regime therefore began to take the necessary steps to expand its business outside France. The career of our merchants, we can define the extraordinary, they are the first merchants of luxury is at the court in Paris is within the imperial Russian and English. Their prices and their taste was considered exceptional and the secret - in the tradition of Poirier - remained to use only the most precious materials and the collaboration of the best architects of Paris, such as cabinetmakers Martin Carlin and Adam Weisweiler and bronze workers Pierre Gouthière and François Remond.

[13] The deeds of Henry IV, in the original language of Francois Marie Arouet The Henriade de Voltaire (Paris 1694 - 1778 therein). Youthful poem, published clandestinely and in abbreviated form in 1722-23 under the title "La Ligue ou Henry Le Grand..."

[14] A signature of Wilhelm Tischbein, Philipp Hackert and Francesco Collecini - dated May 2 1791- is the skill in which "rating for 2600 ducats the frescoes by Fischetti in Lamia gallery casino Carditello, depicting the Apotheosis of Errico IV" ARC, series Amministrazione Carditello e Calvi, v. 622, f. 9, v. 623, f. 40-41, already in L. Migliaccio, Rivisitando Carditello. Nuove acquisizioni archivistiche, in "Bollettino di informazione: tutela, restauro, contributi, iniziative, mostre, manifestazioni”, n. 4, Caserta 1998, p. 79, note 33.

[15] F. Mazzocca, A workshop international foreign artists at the court of Ferdinand IV and Maria Carolina, in The House of King, cit. p. 121.

[16] H. Acton, I Borbone di Napoli, Milano, 1960; G. Rabbit, I Borbone di Napoli, Milan, 1999.

[17] A. Diana, La nascita della dinastia Borbone nella volta della Galleria del Casino di Carditello, in "Siti Reali e Territorio", cit., p. 25.

[18] (September 19, 1551-1589) son of Catherine de 'Medici and Henry II. Within the religious war that broke out in France between 1562 and 1598, after the Edict of Amboise and the [events of the night of St. Bartholomew], we are witnessing the so- called "War of the Three Henrys", an internal conflict involving Henry III, Henry of Guise (the voice of intransigent Catholicism) and Henry of Navarre, a Huguenot and, later, the first representative to the throne of the Bourbon family, that occurred between 1585 and 1589 . The events of that conflict, which will result in the murder of both Henry of Guise and of Henry III, will be resolved only with the promulgation of the Edict of Nantes in 1598. The civil and religious war that divided France between 1562 and 1598 was one of the most dramatic religious wars that plagued Europe in the sixteenth and seventeenth centuries. As a result of the Lutheran and Calvanist reformantions, the war between Huguenots and Catholics that occurred in France, also represented a conflict between political factions for control of the country and was one of the most significant moments of the process that led to the formation of a state.

[19] «Almost to specify that the Bourbon dynasty is not born by chance but is the result of a project" [upper] ", wanted by the true" Light ", which refers to the female figure as a witness signifier: architecture (team, compass and levels), sculpture (hammer and chisel), painting (palette and brushes), science (globe and telescope), knowledge (an open book and another closed) and the art of war (a sword and a helmet)». 
[20] «Obvious references to Masonic culture are: the signs of the zodiac, the number five, how many are the Bourbon kings represented, open book, the acacia branch, the temple. In particular the construction of a temple ideal based on the exercise of virtue - whose design is inspired by that of King Solomon in Jerusalem - is one of the ultimate goals of the ideology and commitment of Masonic Masons, as it is known, is the 'building of the temple the ideal of their existence, a temple that was to be built through the exercise of reason, the practice of virtue and brotherhood » in A. Diana. La nascita della dinastia Borbone nella volta della Galleria del Casino di Carditello, in "Siti reali e Territorio", cit., p. 25.

[21] R. Lattuada, Neapolitan painting in his dealings with Luigi Vanvitelli and the court of Caserta; F. Strazzullo, Lettere di Luigi Vanvitelli, vol. II, letter n. 707. 